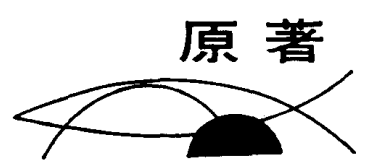

\title{
蒸気滅菌装置の蒸気使用量測定々 スチームフィルタの使用経験
}

\author{
古橋 正 吉* \\ Measurement of Steam Consumption in Steam Sterilizers \\ and Effectiveness of Steam Filters \\ Masayoshi Furuhashi \\ Dept. of Operating Center, \\ Hospital Attached to the Faculty of Medicine, \\ Tokyo Medical and Dental University, \\ I-5-45 Yushima Bunkyo-Ku, Tokyo 113, Japan
}

\begin{abstract}
Quantity of steam consumed mainly by steam sterilizers were measured. Impurities in steam were also observed by installing steam sterilizers.

1) Steam consumption in the central sterile supply department per day was $6 \%$ of steam for processes in the whole hospital. $25 \%$ of steam consumption in the central supply department was heat loss. Steam consumption marked the highest during the operating time of water sterilized-distillers amongst other equipment. Steam consumption by steam sterilizers marked the highest during a pre-heating time for a jacket. This value should be taken into consideration in designing a steam pipe line or boiler capacity. The hourly steam consumption was only one third of the highest other than that of the pre-heating time.
\end{abstract}

2) Alkalinity $\left(\mathrm{CaCO}_{3}\right)$, hardness, $\mathrm{SO}_{4}{ }^{3-}, \mathrm{PO}_{4}{ }^{3-}$, and $\mathrm{pH}$ showed standard value. The degree of contamination of the steam filter element was also observed 6 th months after installation. The filter element was obviously contaminated by impurities in steam. Steam filters were quite effective in removing impurities in steam.

3) Electron microscope and X-ray analysis proved to be more reliable than normal chemical analysis in analising elements of stains placed on the stainless steal bar by impurities in steam.

\footnotetext{
* 東京医科歯科大学医学部付属病院・手術部 （原稿受付：昭和60年10日30日）
} 


\section{はじめに}

病院のプロセス用エネルギーは, 給湯, 給食, 洗濯, 浴室および滅菌用として利用されている。 このうち，蒸気の利用が大部分を占めている。

本研究の目的は, 病院に抢けるエネルギ一使 用量の調查の一環として東京医科歯科大学医学 部付属病院 (東京都文京区) 中央滅菌材料部之 手術部の蒸気消費量を実測した。蒸気滅菌装置 の蒸気消費量の時間変化の測定についての研究 報告はほとんどない。さらに, 蒸気滅菌装置に 米国製 Steam filter を取りつけて，蒸気ドレ ーンに含まれる不純物の除去効果を検討した. 不純物については化学分析执よびX線分析法な ぞで研究した.

\section{研究方法}

\section{1. 蒸気消費量の測定}

エネルギーセンターより中央材料部にくる高 圧蒸気管 (圧力 $5 \mathrm{~kg} / \mathrm{cm}^{2}$ ) の配管 (80A) に 積算式蒸気流量計（シャント形翼車メーター： VF, OVM-101, SUNFLAME SEIKI Co. Ltd. Tokyo）を取りつけた（1980年 8 月）.

中央材料部の高圧蒸気配管には蒸気滅菌装置 8 台と蒸留水製造装置 (蒸気を凝縮して蒸留水 を作る洗浄後の仕上げ用）2台およびエチレン オキサイドガス滅菌装置 1 台が接続されている (表 1 ).

\section{表 1 中央材料部の蒸気利用機器}

\begin{tabular}{|c|c|c|c|}
\hline 機 器 の 種 類 & 台娄 & 内筒容積 & 外筒容積 \\
\hline $\begin{array}{l}\text { ハイスピード蒸気滅菌装置 } \\
\text { 中 型 蒸 気 滅 菌 装 置 } \\
\text { エチレレンオキサイドガス滅 } \\
\text { 菌装置 }\end{array}$ & $\begin{array}{l}2 \\
4 \\
1\end{array}$ & $\mid \begin{array}{c}0.12 \mathrm{~m}^{3} \\
0.59 \\
0.32\end{array}$ & $\begin{array}{l}0.04 \mathrm{~m}^{3} \\
0.17 \\
0.07\end{array}$ \\
\hline $\begin{array}{r}\text { 蒸 留 水製造 装 置 } \\
\text { 局 }\end{array}$ & $\begin{array}{l}1 \\
1\end{array}$ & $\begin{array}{l}\text { 製造能力 } \\
\text { 製造能力 }\end{array}$ & $\begin{array}{l}300 l / h \\
200 l / h\end{array}$ \\
\hline
\end{tabular}

中央材料部全体の蒸気消費量は15分ごとに測 定した. 蒸気滅菌装置の蒸気消費量測定は 1 分 ごとに測定した。ただし, 流量計の測定範国

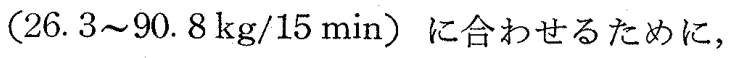
蒸気滅菌装置 (内筒容積 $0.59 \mathrm{~m}^{3}$ ) 4 台を並列 運転して毎分ごとの蒸気消費量を求めた。

なお，蒸気消費量注すべて配管熱損失 $(0.7$ $\mathrm{kg} / \mathrm{min}$ ）を差引き 1 台当りに換算して測定值 とした。 なお中材の滅菌装置の一部は手術部が 共用している.

\section{2. 蒸気中の不純物の測定}

中央手術部専用の蒸気滅菌装置 3 台に Steam filter (23, Slush 75, BALSTON FILTER PRODUCTS, Massachusetts, U.S. A. : 図 1 ) を滅気滅菌装置の蒸気配管の 1 次側と 2 次側の 中間の位置に取りつけた（図 2 ). Steam filter 取りつけ後，1 次側，2次側およびボイラ一高 圧蒸気管の 3 力所から蒸気ドレーンを 1 日 3 回 採取した（図 3 の註参照).

蒸気ドレーンについて, アルカリ度, 硫化物, リン酸化合物の含有量, 硬度, $\mathrm{pH}$ などを水質 試験法 (日本薬学会, 1980 年) ${ }^{52}$ に準拠して測 定した. 総アルカリ度 $\left(\mathrm{CaCO}_{3}\right.$ として) は中 和滴定法, 硫酸イオン $\left(\mathrm{SO}_{4}{ }^{2-}\right)$ はクロム酸バリ ウム吸光度法, リン酸イオン $\left(\mathrm{PO}_{4}{ }^{3-}\right)$ はモリブ デン青吸光度法, 総硬度は EDTA 法, $\mathrm{pH}$ はガ ラス電極 $\left(15^{\circ} \mathrm{C}\right)$ でそれぞれ測定した．同時に 対照としてスチームテストキット (CHEMETRICS Inc., Calverton, Virginia, U. S. A.) を 併用して測定した.

なお, Steam filter 性能の確認を目的として オートクレーブ・テストバー（ステンレス鋼製,

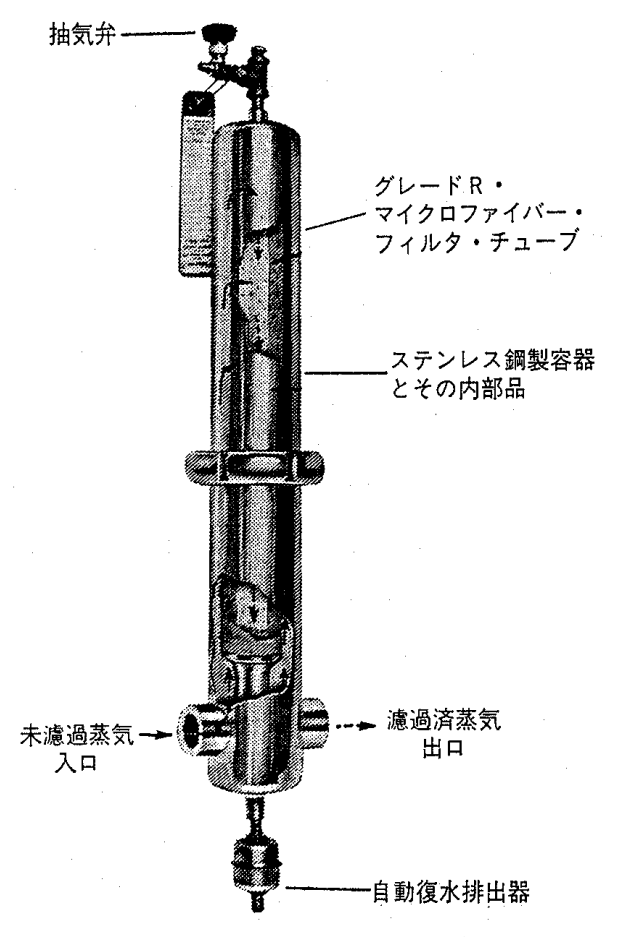

図 1 スチームフィルタの構造 


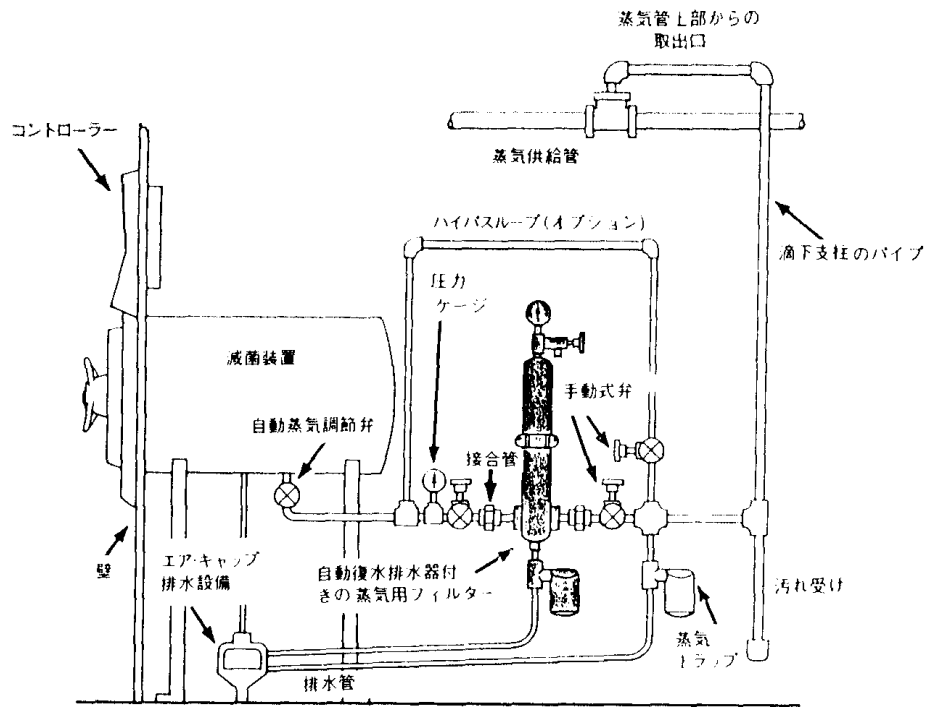

図 2 スチームフィルタの設置部位

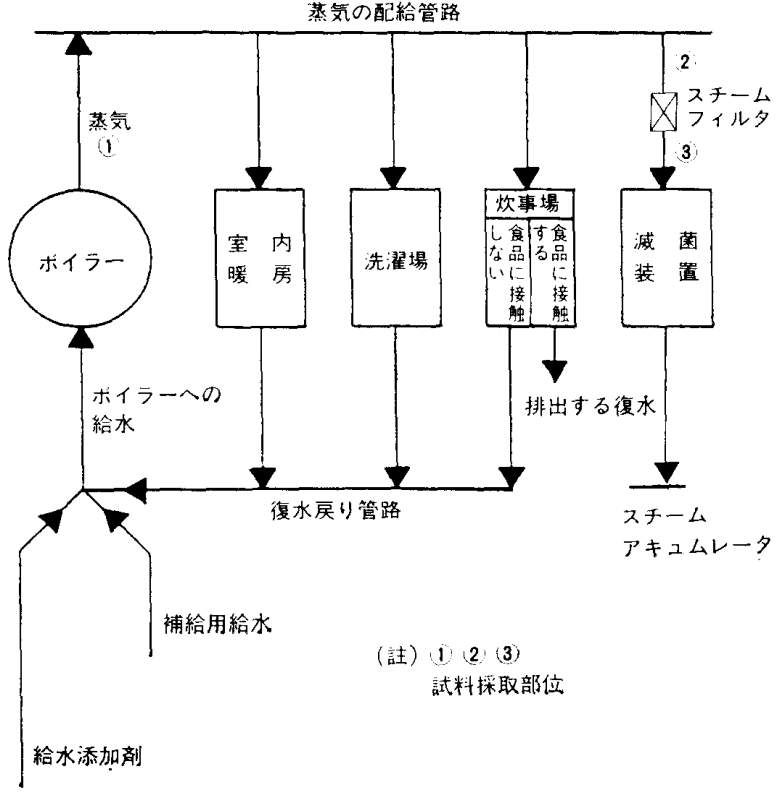

図 3 病院における蒸気供給システムと試料採 取部位

15. $2 \times 5 \mathrm{~cm}$, 得さ $2 \mathrm{~mm}$ : CODMAN \& SHURTLEFF Inc. Massachusetts, U.S.A.) 存 蒸気滅菌し，テストバー表面に付着した蒸気中 の不純物を䛇べた。この分析には，電子顕微鏡 (HFS-2 型，日立製作所) 拉よびェネルギー 分散型X線分析装置（Kevex-5100 型，日立製 作所）を併用してマイクロアナーリスを尖施し た。

\section{研究成 績}

\section{1. 蒸気滅菌装置の蒸気消費量}

蒸気滅菌装置は, 真空, 滅菌, 乾燥の各工程
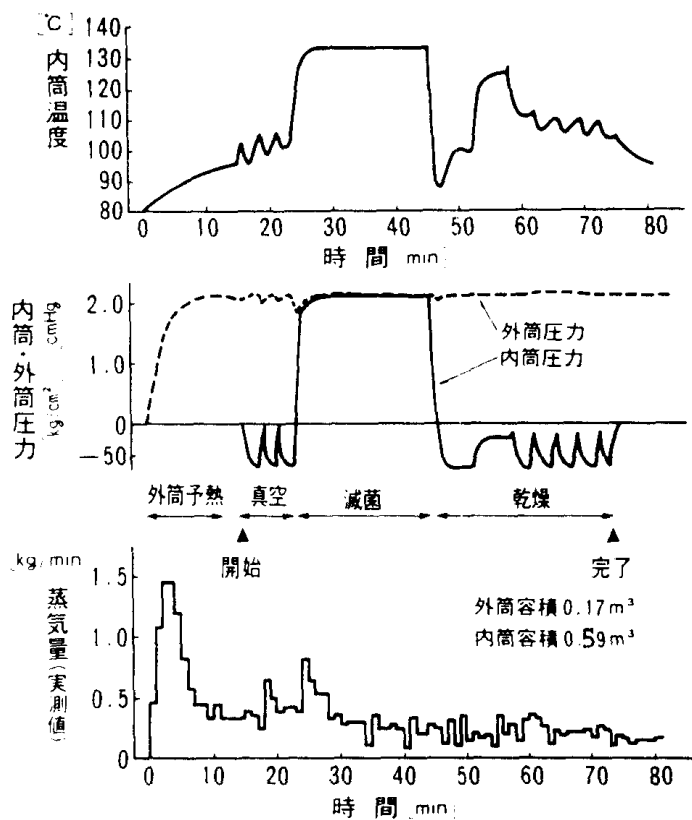

図 4 滅菌器の内筒温度・内外筒圧力・蒸気量 の時間変化

が自動運転される。

蒸気減菌を行って，每分蒸全消費量の1台当 りの推移を図 4 に示した。

図 50 上段は队简温恔，中段は内筒と外筒の 玨少 $\left(\mathrm{kg} / \mathrm{cm}^{2}\right.$, 真空は $\mathrm{mmHg}$ で示す), 下段 は蒸気消費量（毎分）を示した。温度，生力は 蒸気減菌装置付属の自記記録計で測定した。

蒸気減菌装置 1 古の蒸気消費量の最大のビー 夕 $(1.5 \mathrm{~kg} / \mathrm{min})$ は, 朝の最初の外筒予熱恃に 生じた。このピークは約 8 分間で低下し，以後 は外筒の放熱により一定 $(0.32 \mathrm{~kg} / \mathrm{min})$ とな 
った.この間に, 外筒圧力は次第に上昇し 2.2 $\mathrm{kg} / \mathrm{cm}^{2}$ に達した. 以後, 内筒の真空工程を除 きこの圧力が持続した. 次に, 真空工程におい て，蒸気供給と真空ポンプの作動が交互に行わ れ, 蒸気供給のたびに蒸気消費量は上昇し,こ の間に内筒温度は $86^{\circ} \mathrm{C}$ に上昇した。

滅菌工程に入ると，その最初に第 2 のピーク $(1.0 \mathrm{~kg} / \mathrm{min})$ を生じた。これは，滅菌物をの せた台車，金属容器 (カス卜等) および内筒の 屝，後方のバッフル板が加熱されるための負荷 と考えられる．滅菌工程は21分間だがこの間は 内筒圧力と温度は $2.1 \mathrm{~kg} / \mathrm{cm}^{2}, 132^{\circ} \mathrm{C}$ で一定 に保たれた。蒸気消費量は $0.32 \mathrm{~kg} / \mathrm{min}$ であ った.

次に, 乾燥工程に入ると, 再び内筒圧力がパ ルゼーション(脈動) して, $-100 \sim-700 \mathrm{~mm}$ $\mathrm{Hg}$ の範囲を変動した。この間の蒸気消費量は ほぼ一定でで $0.24 \mathrm{~kg} / \mathrm{min}$ あった（図 5 ).

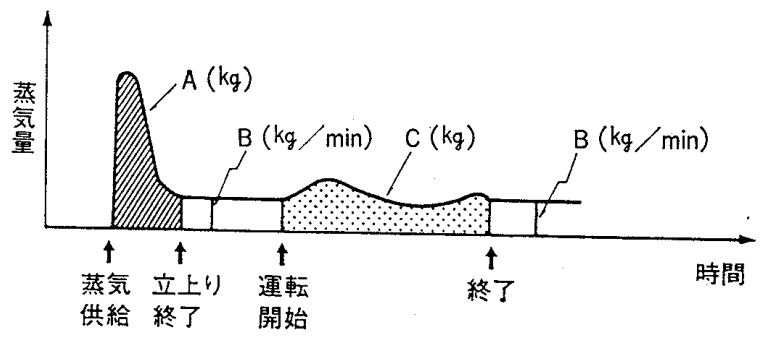

図 5 蒸気滅菌装置の蒸気消費量推移
$\mathrm{A}$ ：外筒の立上り（朝の1回目）
$\mathrm{B}:$ 外筒蒸気消費量
$\mathrm{C}:$ 滅菌中の蒸気消費量

以上で第 1 回目の滅菌が終了した. 次いで第 2 回の同じ滅菌操作を行うときには, 内筒, 外 筒の予熱はすでに終了しているので，外筒予熱 のための蒸気消費量のピークは生じない，また， 内筒予熱のピークも第 1 回目にくらべるとやや 低くなる.

以上第 1 回目の, 滅菌実施中の蒸気消費量の 総和は，1台当りで，外筒予熱時 (11分間) $8.3 \mathrm{~kg}$, 外筒予熱の保持 (8 分間) $2.5 \mathrm{~kg}$, 真 空工程 (8 分間) $3.3 \mathrm{~kg}$, 滅菌工程 (21分間) $8.3 \mathrm{~kg}$, 乾燥工程 (28分間) $6.7 \mathrm{~kg}$, 合計 76 分 間, $29.1 \mathrm{~kg}$ となった.

第 2 回目以降の滅菌実施では第 1 回目々異な り外筒予熱がないため, 滅菌全工程の蒸気消費 量は少ない, 真空工程 $3.6 \mathrm{~kg}$, 滅菌工程 $7.1 \mathrm{~kg}$,
乾燥工程 $6.7 \mathrm{~kg}$, 合計 60 分間, $17.4 \mathrm{~kg}$ であっ た.

外筒よりの放熱は滅菌の全操作中にわたって 持続し，その合計は $23 \mathrm{~kg}$ に達した。これは 全消費量の $90 \%$ 近くに達する。この $23 \mathrm{~kg}$ に は，外筒からの放熱のほかに，蒸気トラップに 設けたスリットからの蒸気損失む含まれており， むしろ後者が支配的亡考える。

\section{2. 蒸気利用機器の蒸気消費量}

蒸気滅菌装置以外に蒸気を利用寸る蒸留水製 造装置を加えて蒸気消費量を検討した.

測定は，中央材料部の蒸気消費量を1980年 9 月 3 日から 3 日間にわたり 15 分ごとに測定した. 蒸気滅菌装置と蒸留水製造装置および配管の熱 損失など蒸気消費量の内訳を表 2 に示した。 1 日当りの消費量は蒸気滅菌装置が平均 $842.6 \mathrm{~kg}$, 蒸留水製造装置 $515.8 \mathrm{~kg}$, 配管の熱損失 $420 \mathrm{~kg}$, 合計 $1,778 \mathrm{~kg}$ となった.

表 2 、蒸気利用機器の蒸気消費量内訳 $(\mathrm{kg} / \mathrm{day})$

\begin{tabular}{|c|c|c|c|}
\hline & $\begin{array}{c}9 \text { 月 } 3 \text { 日 } \\
\text { (水) }\end{array}$ & $9 \underset{\text { (木) }}{9 \text { 月 }}$ & ${ }^{9}$ 月 5 日 \\
\hline 蒸気滅菌器 (合計 6 台) & 841.2 & 847.7 & 838.9 \\
\hline 蒸留水製造装置 (2 台) & 599.2 & 363.3 & 585.1 \\
\hline 配 管 熱 損 失 & 420.0 & 420.0 & 420.0 \\
\hline 計 & $\mid 1,860.5$ & $1,631.0$ & $1,844.0$ \\
\hline
\end{tabular}

3 日間のらち，代表的な日と考えられる 9 月 3 日（水曜日）の蒸気消費量の時間変化を図 6 に示した. 図中の点線は蒸気消費量の実測值, 実線は計算值である。実測值と計算値の差が大 きくなった部分は，流量計の測定範囲を外れた 場合に生じた。

9 月 3 日の運転回数は, 蒸気滅菌装置 (4 台) 12回，ハイスピード蒸気滅菌装置（2台）10回， エチレンオキシドガス滅菌装置 (1 台) 2 回, 蒸留水製造装置 (2 台) は蒸気利用時間 105 分, と90分間であった。 9 月 3 日のピークは， $\mathrm{AM}$ $9: 15 \sim 9.30$ の 15 分間当り $90 \mathrm{~kg}(6 \mathrm{~kg} / \mathrm{min})$ で あった。

上記の 3 日間について，1日当りの手術件数， 減菌物の容量 $\left(\mathrm{m}^{3}\right)$ を調查して毎日の蒸気消費 量との相関をしらべたがいずれも相関はなかっ た。しかし, 蒸気消費量は蒸留水製造装置の通 蒸気時間, 外筒の予熱延べ時間とに相関するこ 


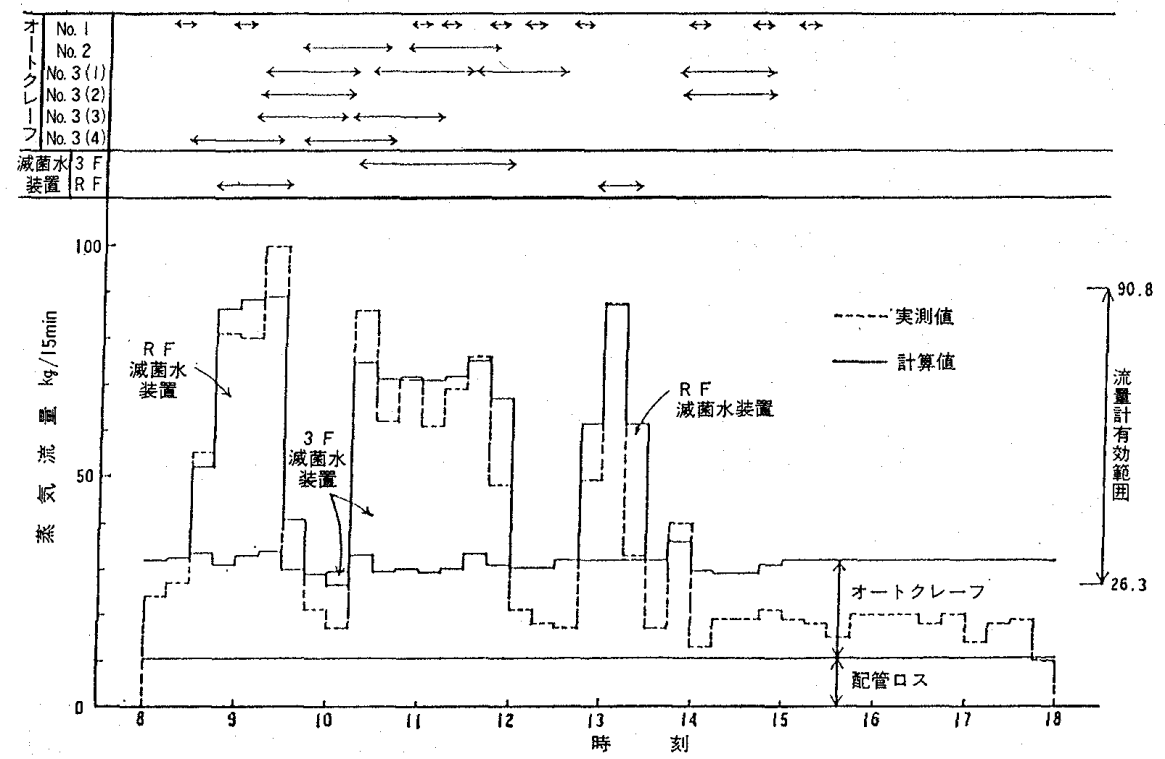

図 6 蒸気利用機器の運転時間と蒸気流量の時間変化

表 3 蒸気ドレーンの化学分析成績

\begin{tabular}{|c|c|c|c|c|c|}
\hline 項 目 $^{\text {採取部位 }}$ & $\begin{array}{l}\text { ボイラー } \\
\text { ドレーン }\end{array}$ & 1 次 側 & 2 次 側 & $\begin{array}{l}\text { 氛水分離器 } \\
\text { 烝 留 水 }\end{array}$ & 水 道 水 \\
\hline $\begin{array}{c}\text { 総アルカリ度 } \\
\left(\mathrm{CaCO}_{3}\right)\end{array}$ & $\begin{array}{l}10> \\
(2.0)\end{array}$ & $\begin{array}{l}10> \\
(1.3)\end{array}$ & $\begin{array}{l}0 \sim 10> \\
(1.9)\end{array}$ & $10>$ & 24 \\
\hline 総 硬 度 & $\begin{array}{c}2.2 \\
(1.2)\end{array}$ & $\begin{array}{c}2.3 \\
(2.3)\end{array}$ & $\begin{array}{c}2.0 \\
(1.1)\end{array}$ & 2.0 & 75 \\
\hline $\mathrm{SO}_{4}{ }^{2-}$ & $\begin{array}{c}2.7 \\
\text { （検出せず） }\end{array}$ & (検出せず) & $\begin{array}{c}1.8 \\
\text { （検出せず） }\end{array}$ & 2.0 & 2.0 \\
\hline $\mathrm{PO}_{4}{ }^{3-}$ & $\left(\begin{array}{c}0 \\
(0.02>)\end{array}\right.$ & $(0.02>)$ & $\left(\begin{array}{c}0 \\
(0.02>)\end{array}\right.$ & 0 & 0 \\
\hline $\mathrm{pH}\left(15 \mathrm{C}^{\circ}\right)$ & $\begin{array}{l}6.5 \\
(6.50)\end{array}$ & $\begin{array}{c}6.05 \\
(5.30)\end{array}$ & $\begin{array}{c}6.07 \\
(5.40)\end{array}$ & 6.5 & 7.0 \\
\hline
\end{tabular}

単位: ppm

とが判った。

なお，10月16日から翌年1月13日までの期間 に，1日ごとの蒸気消費量を実測したが，この 間のピークは11月 4 日(火曜日)の $3,096 \mathrm{~kg} /$ day であった。

当病院のプロセス用（給湯, 給食, 洗濯, 滅 菌を目的とする) 蒸気は，10月の実測によると 1 日当たり $28 \mathrm{t} / \mathrm{a}$ 前後であるので, 中央材料 部の蒸気消費量の割合いはその $6 \%$ 前後にすぎ ない。

\section{3. 蒸気に含まれる不純物の化学分析}

試料採取は, ボイラ一, 蒸気滅菌装置のSteam filter の 1 次側と 2 次側の給蒸管からそれぞれ ドレーンを採取した(図 3 の註). 同時に蒸留水 製造装置の蒸留水および水道水を対照として化
学分析を実施した。

総厂ルカリ度 $\left(\mathrm{CaCO}_{3}\right)$, 総硬度, $\mathrm{SO}_{4}{ }^{2-}$, $\mathrm{PO}_{4}{ }^{3-}, \mathrm{pH}\left(15^{\circ} \mathrm{C}\right)$ の測定結果を表 3 に示した. 表 3 の数值はスチームテストキットによる測定 值（平均值）であり，カッコ内は，水質試験法 にもとづく測定值 (平均值) である.

ボイラードレーン, Steam filter の1次側と 2 次側のドレーンを比較したが分析值に著しい 差はなかった。 また，時間差や日差も認めなか った.

蒸気ドレーンの不純物はこの化学分析值をみ る限り，不純物は僅かであり標準的であるとい える。しかしながら，Steam filter 設置後 6 カ 月経過した時点でフィルタ沪材を取り出して観 察したところ，茶褐色に変色していた（図 7 ）. 


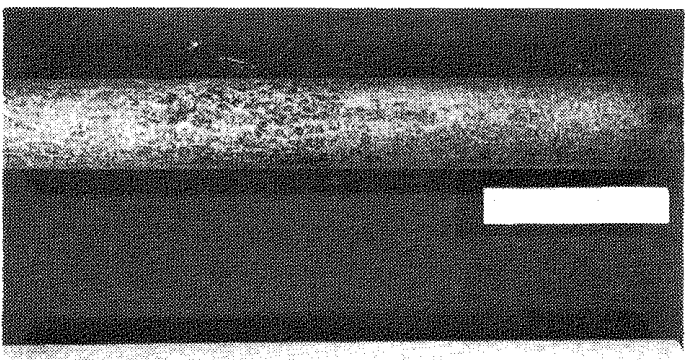

\section{図 7 Steam filter の沪材}

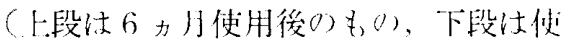

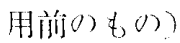

これは蒸気中の不純物がたとえ微量であっても， 長期間の間に徐々にフィルタに捕集されたこと 老示す。蒸気ドレーンの断片的な化学分析法で は奉態を明らかにすることはできないため次に 述バるマイクロアナリシスを実施した。な抏， 当院のボイラーでは清缶剤 (Mascot ${ }^{\mathrm{R}}$, MX-8. FUSAMORI INDUST. Co., Tokyo) を使用L ている。この清午剤の主成分は不明だがリン酸 系化合物は含まれていない。

\section{4. 蒸気不純物の $X$ 線分析}

蒸気滅菌装置の内筒表南をくまなく研磨して 表洎の污染物を予如除去してから奏験を行一た。

ステンレス鋼板（鏡面と梨地面）を蒸気滅菌 装置内筒に直接い机て隇菌, 乾燥厂程を経てか ら取り出した。ステンレス鋼板の鏡面部と梨地 部分の表面に付着した「しみ」在観察してこの しみ」を試料とした（网8）。

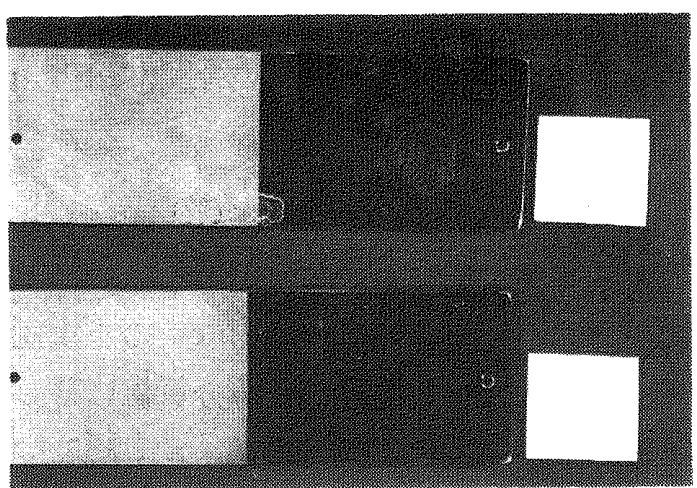

図 8 オートクレーブ・テストバーの「しみ」 上段は Steam filter 在ハスしないと き，下段はパスした埸合.テストバー は右側が鏡面部分，支:側は梨地部分上 なっている。

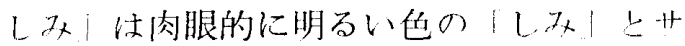

ビのような茶褐色の「しみ」が琶められた。茶 褐色の!しみ」はSteam filter 通した蒸気 では発生しなかったが明るい色の「しみ」が観 祭された。全属表面の「しみ」の分析は通常容 岉ではないが，筆者はステンレス鋼板上の「し み」在特殊テープに転写した。これを電子顕微 鏡ならびにX線分析装置を併用して分析子る少 法を採用した。

分析装置汇走查型電子顕微鏡 (HFS-2 型, 日立製作所）执よびエネルギー分散型 $\mathrm{X}$ 線分析 装置（Kevex 社，5100 烈，日製産業株式会社） 在用い半定量分析を行った。
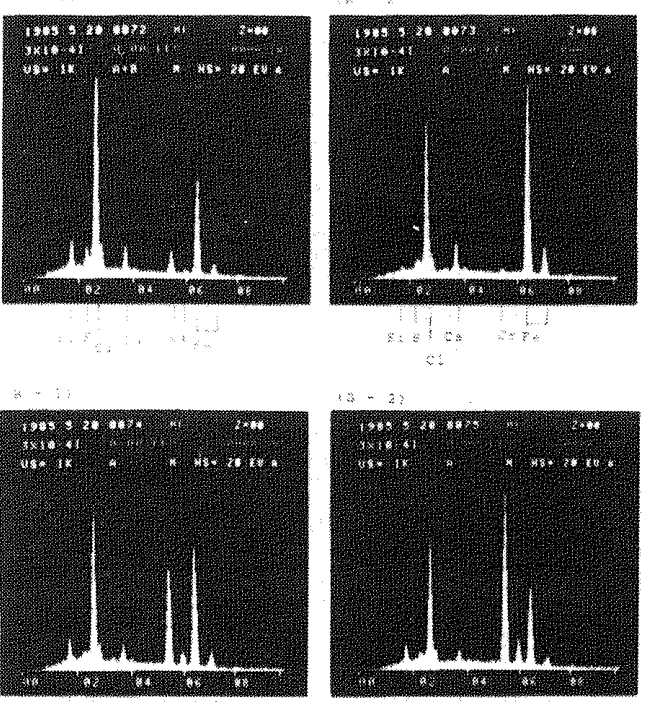

図9|しみ|のX線スペクトルによる分析

间9にX線スペクトルの1例を示した。この 結果, $\mathrm{Cl}, \mathrm{Fe}, \mathrm{Cr}, \mathrm{Ca}, \mathrm{Si}, \mathrm{S}$ が検出されたが， これは「しみ」の成分と推定された。この元素 はテストバーの鏡解部と梨地部分に付着した |しみ、|のす心゙てに共通して検山した。次に， |しみ、の結晶構造解析のために「しみ」を搔 きとり，純水に溶解した。この試料を赤外線ス ベクトル，紫外線スぺクトルおよび NMR ス ベトルで癿共分析を行った。

この結果，紫外線スペクトルで $275 \sim 280 \mathrm{~nm}$ に㮖かに吸収が認奴>C=0 と考えられ た。このほか，C，H，Oで構成される物質が検 鹏された。しかし，ポイラーの清缶耠に由来す

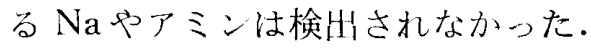

C，H，（）構成の化命物は Steam filter $の$ 素 
材である glass fiberの binder である polyvinylidine fluoride resin (U.S. A. Federal Regulations \# 177. 2510, attached) が何かの原闲で 微量検出されたもの上考える。

\section{考察}

病院のエネルギー消費量の調查の一-環として, 中央滅菌材料部之手術部に扮ける蒸気消費量を 実測した。蒸気滅菌装置を主とした蒸気利用機 器の蒸気消費量を時間ごとに追求した報告注 とんどない。また，蒸気中の不純物を除去する 日的として Steam filter 設置して，その效 果について研究した1,6).

\section{1. 蒸気消費量とその時間变化}

中央材料部全体の 1 日当りの蒸気消費量は病 院のプロセス用蒸気量の $6 \%$ であった。病院で は給湯が全体の1/4を占め, 洗潄, 的房がこ扎に 続いて多かった。

中央材料部で苜気利用機器を全部運転して蒸 気消費量を測定した。そのピークは蒸留水製造 装置を運転したときに生じ，蒸気消費量は 90 $\mathrm{kg} / 15 \mathrm{~min}$ であった。蒸気滅菌装置だけを運転

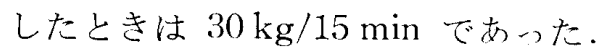

蒸気減菌装置の蒸気消費量のピークは，1日 の最初の運転で外筒の予熱の恃に発生し， $1 \frac{1}{\mathrm{i}}$ 当り $1.45 \mathrm{~kg} / \mathrm{min}$ となった。侍閒当りでは 87 $\mathrm{kg} / \mathrm{h}$ となる。この数值をもって蒸気供給管や ボイラー容量の設計上の基準にすべきである。 しかし, 蒸気滅菌装置のメ一カ一は蒸気消費量 を $75 \mathrm{~kg} / \mathrm{h}$ としていた。これでは明らかに不 足して抽り今後の設計に当って修正必要と寸 る。

朝の第 1 问目の蒸気滅菌 $\left(2.1 \mathrm{~kg} / \mathrm{cm}^{2}, 132^{\circ}\right.$ C）について全工程（72分間）の蒸気量を测定 寸ると 1 台当り $0.404 \mathrm{~kg} / \mathrm{min}$ (平均), 妝閪当 たりの挨算で $24.25 \mathrm{~kg} / \mathrm{h}$ となった，続いて， 第さ河目の蒸気滅菌では，外简の予熱が終了し ているために蒝気消費量は少なくなり，全工程 （60分閒）で 1 古当り $0.29 \mathrm{~kg} / \mathrm{min}$ ，侍閒掺算 では $17.4 \mathrm{~kg} / \mathrm{h}$ となった。

以上のように, 蒸気減菌の際の蒸気消費量の 50 70\%は外筒表酒からの熱損失である。した がーて，蒸気滅菌装置の運転老休止している川!
には，同装置の蒸気弁を閉鎖ナるようにするこ とが望ましい。

また，蒸気供給管からの熱損失は，中央材料 部全体の蒸気消費量の25\%ていどに達するので, 滅菌業務が終了した侍には, ボィラ一室の蒸気 此弁を閉鎖することが望ましい，

当病院で法, 蒸気滅菌装置の余剩蒸気を又千 一ム・アキュムレータ装置（眝蔵容量：1.4 卜 ン）にレターンさせるシステムを採用している。 これによって夜間，ボイラーから給蒸が停止し. ても蒸気が利用できる。

\section{2. 蒸気中不純物の分析}

蒸気中の不純物に対して Steam filter がど の程度除去効果が女るのかを検討した。

Steam filter は $0.1 \mu \mathrm{m}$ 径以上の微粒子を高 い効率で除去寸るといわ机る ${ }^{3,4)}$.

蒸気ドレーンを水質試験法によって測定した が, ボイラードレン, Steam filter の 1 次側, 2 次側ともに正常範囲の值を示した。ところが， Steam filter 6 力月使用してから取り出して 観祭したよころ沪材は茶裀色に変化していた。 沪材を指で非迫したが硬度は使用前と同じに保 た狆ていた。茶褐色の変色は蒸気中に含まれて いる微量の不純物が徐々に捕集されたことを示 寸。 そこで蒸気中の微量な不純物の性状を追求 寸ることになった。

試料はステンレス製テストバーを蒸気滅菌し て表而に付着した「しみ!である、X線分析の 結果, $\mathrm{Cl}, \mathrm{Fe}, \mathrm{Cr}, \mathrm{Si}, \mathrm{S}$ などが検出された。 また, しみ」の紫外線スペクトル, 赤外線ス ペクトル分析の結果, C, H，Oの元素で構成 さ机る化合物が検卦された，しかし，ボイラー

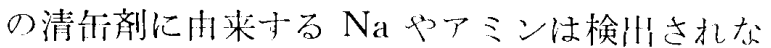
かった。

検杣した元素で構成される化合物はまだ同定 さ机ていない。こ扎らの化合物は Steam filter 在微暈では志るがくぐり抜けできたものである。 ここで「しみ」の発牛原因を推定すると次の条 項目が考えら机た。

(1)蒸気減菌装置の蒸気配管 (Steam filter の1 次側と2次侧の配管含屯）拉上び蒸気滅菌装 置の内筒などの銹び

(2)ボィラーで使用寸る清行剂 


\section{(22) 医器学 Vol. 56, No. 1 (1986)}

(3)Steam filter の沪材の化学成分

このほか，蒸気滅菌を実施中に乾燥工程に問 題があって蔒気不純物が器具の表面に沈着した り, 手術器械の超音波洗浄に使われる洗浄剤が 微量残留寸ることもある。これが手術器具の銹 びの原因となることも経験している。「しみ」 や銹びの発生を防止するためには，上に挙げた 発生原因を追求し，総合的に対策を講じる必要 がある. Steam filter の使用はその対策の一つ の手段として極めて有益であると考える。

\section{結論}

蒸気滅菌装置を中心に蒸気消費量を測定した。 Steam filter を設置して蒝気中の不純物につい ても検討して次の結論を得た。

1）中央材料部全体の 1 日当たりの蒸気消費量 は，病院のプロセス用蒸気量の $6 \%$ であった。 中央材料部全体の蒸気消費量の $25 \%$ は配管から の熱損失であった，中央材料部の蒸気利用機器 のうち，蒸留水製造装置の運転時には蒸気消費 量（時間当り）のピークを生じた。

蒸気滅菌装置の蒸気消費量のピークは外筒の 予熱時に発生した。このピーク值をもって蒸気 供給管やボイラー容量設計の基準值にすべきで ある。

外筒予熱以外の滅菌中の蒸気消費量（時間当

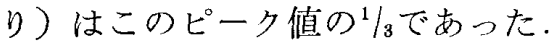

2）蒸気ドレーンの不純物の化学分析の結果, 総アルカリ度 $\left(\mathrm{CaCO}_{3}\right)$, 総硬度, $\mathrm{SO}_{4}{ }^{2-}, \mathrm{PO}_{4}{ }^{3-}$, $\mathrm{pH}$ などは標淮値を示した. Steam filter 設置
後 6 力月して污染状態を観察した. 明らかに蒸 気中の不純物によって filter media が污染さ れていくのが観察された. Steam filter は蒸気 中の不純物除去に極めて効果的であった。

3）蒸気中の不純物がステンレス鋼板上に「し み」を形成した場合，「しみ」の成分分析に電 子顕微鏡とX線分析法を併用したが，単なる化 学分析法よりも詳細な情報が得られ有用である.

（終りに本研究に当りご指導こご援助をいただ いた井上宇市教授, 高島征助氏に厚く御礼申し 上げます）

(本研究の要旨は第 60 回日本医科器械学会大 会で報告した.）

\section{文献}

1）井上宇方，古橋正吉，上田伊佐雄：中央材料部 に扝ける蒸気使用量の実測, 医器学, 51, Suppl., 16-18, 1981 .

2）井上宇市，高井啓明，苌井下興，水野弥一：病 院のプロセス用エネルギ消費寔の実測，空気調 和・衛生工学，56，1，39-54，1982.

3) Balston Filter Products : Bulletin No. P-51, 1984.

4) Strauss, R. and Perrotta, K.: Impurities in Steam, SCORE, 7, 1, 24-29, 1982.

5）日本薬学会編：衛生試験法・注解，水質試験 法, 719 778，金原出版（東京）刊，1980.

6）占橋正吉：スチームフィルタによる蒸気不純物 の除去効果, 医器学, $55,4,228,1985$. 